\title{
KONSEP KONSTITUSI HIJAU (GREEN CONSTITUTION) DALAM KEGIATAN EKONOMI BERKELANJUTAN
}

\author{
Jundiani \\ Yunizar Prajamufti \\ Fakultas Syariah UIN Maulana Malik Ibrahim Malang \\ Mobile Phone : 081803814060 \\ E-mail:jundis3@yahoo.com
}

\begin{abstract}
Abstrak
Object of this research addresses the problem of green constitution concept management in supporting sustainable economic activities. This research applies normative law approach. The result shows that the character of green constitution concept management in running economic activities refers to the essence of human life in nation and state living context which is in line with the five basic principles keeping balance and harmonious relationship with nature. It is the implication of principles in running economic activities based on article 33 of Indonesia State constitution 1945 on forming economic law of Indonesia. Hence, it has been a basic change on perception and national development concept which is integrated with sustainable development. As a result, that condition needs a new pattern towards the establishment of sustainable development economic law.

Obyek kajian penelitian ini mengangkat permasalahan karakteristik pengaturan konsep konstitusi hijau (green constitution) dalam mendukung penyelenggaraan kegiatan ekonomi yang berkelanjutan dan implikasi prinsip-prinsip penyelenggaraan kegiatan ekonomi sebagaimana yang termuat dalam UUD 1945. Metode penelitian menggunakan pendekatan juridis normative. Hasil penelitian menunjukan karakteristik pengaturan konsep green constitution dalam penyelenggaraan kegiatan ekonomi merujuk pada hakikat kehidupan manusia dalam kehidupan berbangsa dan bernegara Pancasila yang senantiasa menjaga hubungan yang selaras dan seimbang dengan alam. Hal tersebut berimplikasi prinsip-prinsip penyelenggaraan kegiatan ekonomi menurut Pasal 33 UUD 1945 yaitu telah dilakukan perubahan yang mendasar pada cara pandang dan konsep pembangunan nasional yang terintegrasi sehingga dibutuhkan pola baru menuju penormaan hukum ekonomi berkelanjutan.
\end{abstract}

Kata Kunci: Konstitusi Hijau (green constituton), prinsip Keberlanjutan, kegiatan Ekonomi.

Kegiatan perekonomian yang dijalankan olehmasyarakatsenantiasa mengarah kepada suatu upaya untuk dapat mewujudkan pemenuhan kebutuhan hidupnya. Kehidupan perekonomian masyarakat bergerak kearah perubahan yang seiring dengan dengan perubahan masyarakat akan kebutuhan hidupnya. Perubahan-perubahan yang demikian itu berpengaruh secara signifikan terhadap perubahan ekologis. Perubahan 
ekologis menurut Moh. Soerjani dapat secara alamiah maupun buatan karena interaksi secara timbal balik antara makhluk hidup dengan sesamanya termasuk dengan bendabenda disekitarnya.

Keperluan hidup manusia sangat bergantung kepada kekayaan alam yang tersedia di bumi sebagai sumber daya alam berupa air, udara dan tanah. Islam memberikan panduan yang jelas bahwa sumber daya alam dan lingkungan merupakan daya dukung lingkungan bagi kehidupan manusia. Oleh karena itu, dalam perspektif hukum Islam menjaga kelestarian alam dan lingkungan hukumnya wajib. ${ }^{1}$ Al-Qur'an menjelaskan secara eksplisit hubungan antar manusia dan lingkungannya dalam surah al-Luqman ayat $20^{2}$ :

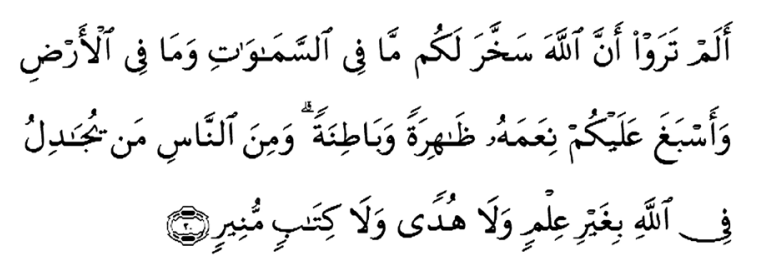

"Tidakkah kamu perhatikan Sesungguhnya Allah Telah menundukkan untuk (kepentingan)mu apa yang di langit dan apa yang di bumi (sumberdaya alam) dan menyempurnakan untukmu nikmat-Nya lahir dan batin. Dan di antara manusia ada yang membantah tentang (keesaan) Allah tanpa ilmu pengetahuan atau petunjuk dan tanpa Kitab yang memberi penerangan."

Berdasarkan arti pentingnya pemenuhan kebutuhan warga masyarakat untuk mendapatkan lingkungan hidup yang baik dan sehat yang merupakan hak asasi dan hak konstitusional bagi setiap warga negara Indonesia sebagaimana telah diatur dalam Pasal $28 \mathrm{H}$ ayat (1) Undang-Undang Dasar 1945 Amandemen Kedua. Pengaturan perlindungan dan pengelolaan lingkungan hidup dalam konstitusi Negara adalah merupakan penegasan arti pentingnya keberlanjutan kehidupan manusia dalam menjalankan ke${ }^{1}$ Mujiyono Abdillah, Agama Ramah Lingkungan Perspektif Al-Qur'an, (Paramadina, Jakarta.: 2005), h. 62. 0.0 .1 giatan ekonomi sebagaimana telah diatur dalam Pasal 33 ayat (4) Undang-Undang Dasar 1945.

Sesuai amanat konstitusi untuk mengelola lingkungan hidup, maka pada tanggal 3 Oktober 2009 telah disahkannya UndangUndang Nomor 32 Tahun 2009 tentang Perlindungan dan Pengelolaan Lingkungan Hidup. Salah satu pertimbangan dikeluarkannya undang-undang tersebut adalah diperlukannya penyempurnaan terhadapundang-undang Nomor 23 Tahun 1997 tentang Pengelolaan Lingkungan Hidup karena diharapkan lebih menjamin kepastian hukum dan memberikan perlindungan terhadap hak setiap orang untuk mendapatkan lingkungan hidup yang baik dan sehat sebagai bagian dari perlindungan terhadap keseluruhan ekosistem.

Perdebatan pengaturan kebijakan perekonomian nasional dan pengaturan hak konstitusional warga Negara dalam konstitusi sudah dimulai sejak akan dilahirkannya konstitusi sebagai dasar penyelenggaraan kehidupan bernegara dan berbangsa Indonesia. The founding fathers masing-masing telah mengemukakan dasar-dasar filosofis penyelenggaraan kegiatan ekonomi nasional dari pendapat/pandangan yang diajukannya dalam rapat-rapat persiapan kemerdekaan Republik Indonesia. ${ }^{3}$ Sejarah perdebatan terulang kembali setelah adanya upaya dilakukannya perubahan Undang-Undang Dasar 1945 berkenaan dengan hak dan kewajiban konstitusional sebagaimana termuat dalam Pasal 28 dan Pasal 33 Undang-Undang Dasar $1945 .{ }^{4}$ Berbagai ragam tipologi konstitusionalisasi ekonomi bermunculan yang sesuai dengan dinamika negara dalam menjalankan kebijakan ekonominya maupun pengaturan hak konstitusional untuk mendapatkan lingkungan yang baik dan sehat yang didasarkan pada dasar kehidupan bernegaranya. ${ }^{5}$

\footnotetext{
${ }^{3}$ Budiman Sinaga: Hukum Konstitusi, (Yoyakarta: Kurnia Kalam Semesta, 2005), h. 72

${ }^{4}$ Dahlan Thaib: Teori dan Hukum Konstitusi (Jakarta: Rajawali Pers, 1999), h. 34
} 
Konstitusi yang memuat hak konstitusional warga Negara maupun kebijakan dalam penyelenggaraan kegiatan ekonomi masingmasing negara dapat dikualifikasikan berdasarkan karakter sebagai negara liberalkapitalistik, negara sosial-komunis dan negara-negara yang tidak menganut kedua paham tersebut. Sehubungan latar belakang masalah di atas maka, fokus kajian penelitian adalah karakteristik pengaturan konsep konstitusi hijau (green constitution) dalam mendukung penyelenggaraan kegiatan ekonomi yang berkelanjutan dan implikasi prinsip-prinsip penyelenggaraan kegiatan ekonomi sebagaimana yang termuat dalam UUD 1945 terhadap pembentukan hukum ekonomi pembangunan Indonesia.

\section{Konsep Pemeliharaan Lingkungan Hidup Dalam Islam}

Menurut pandangan figh kehidupan adalah sesuatu yang sangat mulia dan berharga. Dalam diri setiap makhluk hidup ada sebuah kecenderungan naluri untuk mempertahankan hidup. Manusia sebagai makhluk hidup yang paling mulia dan memiliki kelebihan dari makhluk lainnya karena dibekali oleh Allah akal untuk berpikir ternyata tidak hanya mempunyai naluri untuk mempertahankan hidup tapi juga mempunyai kesadaran untuk mempertahankan hidup. Dari kesadaran dalam diri manusia itulah muncul dan berkembang daya pilih dan upaya yang menyebabkan perkembangan kebudayaan dan peradaban.

Islam mengajarkan bahwa umat manusia wajib melindungi keseimbangan ekosistem. Sebab melindungi keseimbangan ekosistem berarti melindungi optimasi daya dukung lingkungan bagi kehidupan. Sebaliknya, merusak keseimbangan ekosistem berarti merusak optimasi daya dukung lingkungan bagi kehidupan. ${ }^{6}$ Dijeaskan dalam surat alQamar ayat 49:

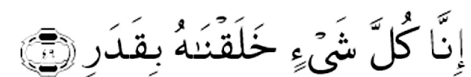

${ }^{6}$ Mujiyono Abdillah, Fikih Lingkungan (Panduan Sosial Berwawasan Lingkungan), (Yogyakarta: UPP AMP YKPN, 2005), h.66
"Sesungguhnya kami menciptakan segala sesuatu (spesies) menurut ukuran (fungsi ekologis masingmasing)."

Dan juga dalam surat al-Maidah ayat 32:

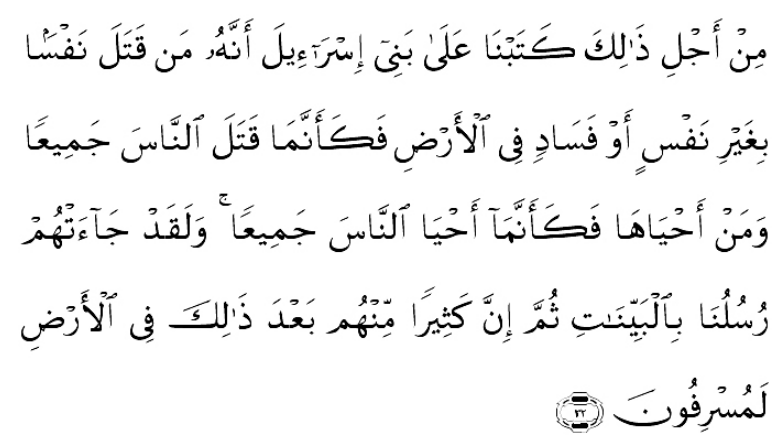

"Oleh Karena itu kami tetapkan (suatu hukum) bagi Bani Israil, bahwa: barangsiapa yang membunuh seorang manusia, bukan Karena orang itu (membunuh) orang lain, atau bukan Karena membuat kerusakan dimuka bumi, Maka seakan-akan dia Telah membunuh manusiaseluruhnya. Danbarangsiapayangmemelihara kehidupan seorang manusia, Maka seolah-olah dia Telah memelihara kehidupan manusia semuanya. dan Sesungguhnya Telah datang kepada mereka rasulrasul kami dengan (membawa) keterangan-keterangan yang jelas, Kemudian banyak diantara mereka sesudah itu sungguh-sungguh melampaui batas dalam berbuat kerusakan dimuka bumi."

Ayat di atas menjelaskan bahwa membunuh spesies tanpa alasan yuridis sama halnya dengan membunuh seluruh spesies. Dengan ungkapan lain menghilangkan salah satu komponen ekosistem sama halnya merusak keseimbangan ekosistem. Dan implikasi yuridis ayat ini adalah manusia wajib menjaga kelestarian seluruh spesies dalam ekosistem. Sebab setiap spesies mempunyai fungsi ekologis masing-masing yang tidak bisa digantikan oleh spesies lainnya. ${ }^{7}$

\section{Konsep Pembangunan Berkelanjutan dan Berwawasan Lingkungan serta Berbasiskan Kerakyatan.}

Pembangunan berkelanjutan dipopulerkan melalui laporan Our Common Future (Masa Depan Bersama) yang disiapkan oleh World Comission on Environment and Development (Komisi Dunia tentang Ling-

\footnotetext{
${ }^{7}$ Mujiyono Abdillah: 68-69.
} 
kungan dan Pembangunan), pada tahun 1987 yang diketuai oleh Gro Harlem Bruntland. Dalam kata pengantar Our Common Future, Gro Bruntland menjelaskan bahwa secara khusus kerangka tugas dari sidang majelis PBB adalah; (1) mengusulkan strategi lingkungan jangka panjang untuk mencapai pembangunan berkelanjutan mulai tahun2000;(2) mengidentifikasikan bagaimana hubungan antar manusia, sumberdaya, lingkungan dan pembangunan dapat diintegrasikan dalam kebijakan nasional dan internasional.

Para anggota komisi meyakini bahwa suatu jalan baru untuk pembangunan perlu ditempuh, yaitu jalan yang akan membawa kemajuan kemanusiaan, tidak saja hanya di beberapa bagian dunia untuk sementara waktu, tapi untuk seluruh bagian dunia dan untuk jangka waktu yang lebih lama. Dan persoalan lingkungan dunia telah ditetapkan sebagai isu utama pembangunan.

Pernyataan yang sering dikutip dari Komisi Bruntland adalah bahwa "pembangunan berkelanjutan merupakan pembangunan yang dapat memenuhi kebutuhan saat kini tanpa mengorbankan kemampuan generasi mendatang untuk mencukupi kebutuhan mereka". Dari pernyataan tersebut setidaknya ada dua konsep kunci, yaitu : (1) kebutuhan, khususnya kebutuhan para fakir miskin di negara berkembang, dan (2) keterbatasan dari teknologi dan organisasi sosial yang berkaitan dengan kapasitas lingkungan untuk mencukupi kebutuhan generasi sekarang dan masa depan. Dengan demikian, pembangunan berkelanjutan, sebagaimana diinterpretasikan oleh Komisi Bruntland, sesungguhnya berangkat dari konsep antroposentrik, yang menjadikan manusia sebagai tema sentralnya. ${ }^{8}$

Komisi mengidentifikasikan tujuh tujuan penting untuk kebijakan pembangunan dan lingkungan, yaitu: (1) memikirkan kembali makna pembangunan; (2) merubah kualitas pertumbuhan (lebih menekankan pada pembangunan daripada sekedar pertumbuhan); (3) memenuhi kebutuhan dasar

${ }^{8}$ Bruce Mitchell, h. 32 akan lapangan kerja, makanan, energi, air dan sanitasi; (4) menjamin terciptanya keberlanjutan pada satu tingkat pertumbuhan penduduk tertentu; (5)mengkonservasi dan meningkatkan sumberdaya; (6) merubah arah teknologi dan mengelola resiko; (7) memadukan pertimbangan lingkungan dan ekonomi dalam pengambilan keputusan. ${ }^{9}$

Dari ketujuh tujuan kebijakan pembangunan tersebut, ada dua hal penting yang sangat membutuhkan perhatian: Pertama, walaupun komisi menyadari bahwa pertumbuhan adalah penting untuk memenuhi kebutuhan dasar manusia, pembangunan berkelanjutan merupakan sesuatu yang lebih dari sekedar pertumbuhan. Kedua, komisi mencatat perlunya keterpaduan antara pertimbangan lingkungan dan ekonomi sebagai strategi utama pembangunan berkelanjutan. Supaya hal ini terwujud, komisi menyimpulkan perlunya perubahan dalam sikap dan tujuan, serta kerangka institusi dan hukum pada setiap tingkatan.

Gagasan pembangunan berkelanjutan di Indonesia telah diupayakan didalam program dan strategi pengelolaan lingkungan sebagaimana tertuang dalam dokumen agenda 21 Indonesia. Agenda 21 Indonesia merumuskan strategi nasional untuk pembangunan berkelanjutan dikelompokkan menjadi empat bidang, yakni : (1) pelayanan masyarakat; Agenda ini menyiratkan bahwa fokus pembangunan dan pengelolaan lingkungan hidup di Indonesia diarahkan pada dimensi sosial-ekonomi, tanpa mengabaikan dimensi lain. Ada enam sub-agenda dirumuskan berkenaan dengan agenda pelayanan masyarakat ini : (a) pengentasan kemiskinan; (b) perubahan pola produksi dan konsumsi; (c) dinamika kependudukan; (d) pengelolaan dan peningkatan kesehatan; (e) pengembangan perumahan dan pemukiman; dan (f) sistem perdagangan global, instrumen ekonomi, serta neraca ekonomi dan lingkungan terpadu..$^{10}$ (2) pengelolaan

\footnotetext{
${ }^{9}$ Bruce Mitchel, h. 32

${ }^{10} \mathrm{Ibid}$.
} 
limbah; dirumuskan untuk memperbaiki kondisi dan kualitas lingkungan hidup manusia serta mencegah proses degradasi lingkungan hidup secara keseluruhan. Lima aspek yang menjadi sasaran utama agenda ini ialah : (a) perlindungan atmosfir; (b) pengeloaan bahan kimia beracun; (c) pengelolaan limbah bahan berbahaya dan beracun; (d) pengelolaan limbah radioaktif; serta (e) pengelolaan limbah padat dan cair. (3) pengelolaan sumber daya tanah; didasari oleh pertimbangan bahwa prosesproses pembangunan yang akan terjadi di Indonesia masih akan ditumpukan pada potensi sumberdaya tanah. Empat subagenda dirumuskan berkaitan dengan hal tersebut, yakni : (a) penatagunaan sumberdaya tanah; (b) pengelolaan hutan; (c) pengembangan pertanian dan pedesaan; dan (d) pengelolaan sumber daya air dan (4) pengelolaan sumber daya alam. ; hal ini didasarkan atas kesadaran akan pentingnya menjaga keanekaragaman hayati. Dan ada tiga sub-agenda yang dirumuskan, yakni: (a) konservasi keanekaragaman hayati; (b) pengembangan bioteknologi, dan (c) pengelolaan terpadu wilayah pesisir dan lautan. Sebagaimana dirumuskan dalam dokumen agenda 21 Indonesia, penanganan bagi ketiga aspek tersebut diarahkan pada upaya-upaya pelestarian dan perlindungan keanekargaman biologi pada tingkat genetik, spesies dan ekosistem, serta menjamin kekayaan alam, binatang dan tumbuhan di seluruh kepulauan Indonesia.

\section{Teori Negara Hukum Kesejahteraan}

Penggunaan teori Negara Hukum Kesejahteraan didasarkan pada pemahaman bahwa negara memikul tanggung jawab dalam mensejahterakan hidup rakyatnya. Di dalam konteks kehidupan bernegara, upaya untuk mensejahterakan rakyat merupakan tujuan utama dibentuknya negara sehingga negara berupaya sepenuhnya dalam memenuhi kebutuhan hidup rakyatnya. Pemahaman ini menjadi pangkal tolak dalam penyelenggaraan kehidupan bernegara ter- masuk pengaturan kegiatan pembiayaan perekonomian masyarakat yang berwawasan lingkungan.

Di dalam negara hukum modern, negara dituntut untuk memberikan pelayanan yang sebaik-baiknya dan seluas-luasnya kepada masyarakat, sehingga semua lapisan masyarakat dapat menikmati kesejahteraan dalam kehidupannya. ${ }^{11}$ Negara Republik Indonesia menganut tipe negara modern, welfare state type. Di dalam mewujudkan kesejahteraan kehidupan warganya, negara Republik Indonesia menekankan pada terciptanya masyarakat adil, makmur dan merata.

Penggunaan konsepsi negara kesejahteraan bagi negara Republik Indonesia akan tampak dari dua fungsi yang dijalankan yakni fungsi regular (regularity function) dan fungsi pembangunan (developing function). Fungsi yang bersifat regular, sering disebut fungsi rutin, yang harus dilaksanakan oleh negara demi kelangsungan kehidupan bernegara. Sedangkan fungsi pembangunan merupakan fungsi yang bertujuan untuk meningkatkan kesejahteraan masyarakat, seperti halnya pelestarian fungsi lingkungan hidup dalam kegiatan perekonomian yang berkembang di masyarakat.

\section{Teori Hukum Pembangunan}

Berikutnya, teori Hukum Pembangunan yang memfungsikan peran hukum dalam aktivitas penyelenggaraan pembangunan nasional. Di Indonesia pernah dikenal Teori Pembangunan Hukum yang dikembangkan oleh Mochtar Kusumaatmadja. Teori tersebut dibangun atas teori kebudayaan Northop, teori orientasi kebijakan (policy-oriented) dari Laswell dan Mc Dougal serta teori hukum pragmatis dari Roscoe Pound. ${ }^{12}$

Teori Hukum Pembangunan sangat memperhatikan nilai-nilai budaya di Indonesia. Teori Hukum Pembangunan dirancang kearah pengembangan ranahranahhukumnetralsepertidibidang transaksi

\footnotetext{
${ }^{11}$ Muchsan, h. 105-106

${ }^{12}$ Mochtar Kusumaatmadja, h. 6
} 
bisnis, perdagangan dan pertambangan. ${ }^{13}$ Teori Pembangunan Hukum menjelaskan bahwa baik teori hukum dari negara-negara barat maupun pemikiran hakikat hukum dari alam pikiran di Indonesia adalah tidak perlu dipertentangkan antara maksud untuk mengadakan pembaharuan hukum melalui perundang-undangan dan penyaluran nilai-nilai atau aspirasi yang hidup dalam masyarakat. Dengan demikian mirip dengan konsepsi law as a tool of social engineering dari aliran pragmatic legal realism, Mochtar $\mathrm{Ku}-$ sumaatmadja mengemukan teori hukum sebagai sarana pembaharuan masyarakat.

\section{Metode Penelitian}

Jenis penelitian ini termasuk dalam penelitian hukum normatif dengan pendekatan juridis-normatif atau yuridis-dogmatis, pendekatan konseptual, dan pendekatan perundang-undangan. Melalui pendekatan juridis-normatif tersebut diharapkan dapat menjelaskan secara obyektif atas permasalahan yang diangkat dalam penelitian ini.

Penelitian hukum normatif merupakan penelitian hukum kepustakaan yang mana sumber bahan hukum penelitian ini hukum primer meliputi peraturan perundang-undangan mengenai konsep green constitution dalam penyelenggaraan kegiatan ekonomi yang berkelanjutan dan berwawasan lingkungan. Studi kepustakaan tersebut dilakukan secara sistematis terhadap peraturan perundang-undangan yang dapat ditelusuri dalam himpunan peraturan perundang-undangan yang ada. ${ }^{14}$ Kajian terhadap bahan hukum yang digunakan tersebut mengarah pada pemahaman yang memadai tentang pengaturan konsep green constitution dalam pengelolaan kegiatan ekonomi yang berkelanjutan.

\section{Hasil dan Pembahasan}

Karakteristik Pengaturan Konsep Green Constitution dalam Kegiatan Ekonomi Berkelanjutan.

\section{Aspek ontologis}

Aspek ontologis mengarah pada permasalahan apa yang merupakan hakikat dari realitas. Konsep kehidupan tersebut beranjak dari inti realitas adalah materi atau ide (gagasan) ${ }^{15}$. Konsep kehidupan beranjak pada dominansi dari inti realitas itu sendiri. Oleh karena di dalam perjalanan sejarah pemikiran manusia akan terjadi dominasi salah satu dari keduanya terhadap yang lainnya sehingga melahirkan aliran materialisme dan idealisme.

Materialisme berpendapat bahwa hakikat dari realitas adalah materi. Segala sesuatu yang ada tersebut disusun oleh materi-materi tertentu. Materi adalah nyata sebagai realitas dasar sedangkan jiwa adalah gejala yang mengikuti materi. ${ }^{16}$ Sedangkan menurut aliran pemikiran idealime bahwa hakikat dari realitas adalah rohani karena prinsip dasar segala sesuatu adalah ide pikiran dan jiwa.

Berikutnya berkembang aliran pemikiran dualisme. Aliran berpikir ini berpendapat bahwa hakikat dari realitas adalah bersumber pada materi dan rohani. Rene Descartes menyebutkan kedua sumber sebagai ruang atau materi berkeluasan (res extensa) dan kesadaran (res cogitans). ${ }^{17}$ Aliran pemikiran dualisme menjadi pandangan pilihan karena dapat menjelaskan secara langsung keberadaan atau hakikat dari realitas kehidupan manusia. Berdasarkan aliran pemikiran dualisme maka hakikat dari realitas hubungan manusia dengan sesamanya dan alam sekitarnya dapat didasarkan materi dan rohani.

Konsepsi kehidupan manusia dan lingkungan hidup pada hakikatnya merupakan konsepsi yang terdiri atas dua komponen

\footnotetext{
${ }^{15}$ A. Mukthie Fadjar, h. 24.

${ }^{16}$ Harold H. Titus, h. 200.

${ }^{17}$ Ibid.
}

${ }^{13}$ Sidharta, h. 422

${ }^{14}$ P.M. Hadjon, h. 14. 
dalam satu bangunan yang saling menguatkan. Penentu kehidupan manusia dan kondisi lingkungan hidup pada dasarnya akan kembali pada manusia sendiri. Hal ini berarti konsep yang dikembangkan di dalam kebijakan, hukum, peraturan perundangan di bidang lingkungan hidup pada dasarnya bersumber dari penyikapan manusia yang berpangkal tolak pada pertimbangan moralnya terhadap lingkungan hidup. Pola kegiatan ekonomi yang dijalankan oleh warga masyarakat membutuhkan konsepsi pengelolaan lingkungan hidup sebagaimana yang telah diamanatkan oleh Undang-Undang Nomor 32 Tahun 2009 tentang Perlindungan dan Pengelolaan Lingkungan Hidup yang menghendaki agar lingkungan hidup ini tetap baik dan sehat.

\section{Aspek epistemologis}

Pengaturan hukum yang berkembang dan dimanfaatkan dalam kehidupan manusia adalah asas-asas, norma hukum dan institusi hukum yang dianggap telah mengakomodasi berbagai kepentingan manusia termasuk hubungan antar manusia dengan alam sekitarnya dan lingkungan hidup. Konsep hukum yang dikembangkan dengan pendekatan analitis mekanistis memberi kesan menguatnya ciri normatif dari hukum. Sebagai ciri normatif dari hukum adalah penegasan asas-asas, norma hukum dan institusi hukum dalam memenuhi kebutuhan manusia akan kepastian hukum, keadilan dan kemanfaatannya.

Berdasarkan arti pentingnya pemenuhan kebutuhan masyarakat dalam lingkungan kehidupannya, maka pada tanggal 3 Oktober 2009 telah diundangkan suatu Undang-Undang yang mengatur pengelolaan lingkungan hidup, yakni Undang-Undang Nomor 32 Tahun 2009 tentang Perlindungan dan Pengelolaan Lingkungan Hidup. Salah satu pertimbangan dikeluarkannya Undang-Undang tersebut adalah diperlukannya penyempurnaan terhadap Undang-Undang Nomor 23 Tahun 1997 tentang Ketentuan-
Ketentuan Pokok Pengelolaan Lingkungan Hidup karena berkembangnya kesadaran kehidupan bermasyarakat dalam pengelolaan lingkungan hidup untuk mencapai tujuan pembangunan berkelanjutan yang berwawasan lingkungan.

Salah satu segi kehidupan masyarakat yang dapat menimbulkan masalah hukum di bidang lingkungan sehingga membutuhkan pengembanan hukum praktis dan penyelesaian masalah hukum adalah kegiatan ekonomi yang dilaksanakan oleh warga dilingkungan kehidupannya. Bank sebagai lembaga yang menjalankan fungsi intermediasi, menurut Undang-Undang Nomor 10 Tahun 1998 menyalurkan kembali dan yang telah dihimpun dari masyarakat kepada masyarakat, memegang peranan penting dalam perubahan ekosistem karena dapatmenggerakkan kegiatan perekonomian masyarakat.

Pengaturan hukum pembiayaan kegiatan usaha yang berwawasan lingkungan yang dijalankan oleh kalangan perbankan, telah dituangkan dalam beberapa ketentuan sebagai berikut: (1) Surat Edaran Bank Indonesia Nomor: 21/9/UKU/1989 tentang Kredit Investasi dan Penyertaan Modal, yang pada pokoknya mengatur ketentuan Perbankan hendaknya memperhatikan AMDAL; (2) Surat Keputusan Direktur Bank Indonesia Nomor: 31/24/KEP/ DIR/1989 tentang Proyek Kredit Mikro yang pada pokoknya mengatur ketentuan kredit tidak digunakan untuk usaha yang merusak lingkungan; (3) Undang-Undang Nomor 7 Tahun 1992 dan Undang-Undang Nomor 10 Tahun 1998 tentang Perbankan yang pada pokoknya mengatur ketentuan hasil AMDAL bagi usaha besar dan berisiko penting; (4) Peraturan Bank Indonesia Nomor 7/2/2005 dan Surat Edaran Bank Indonesia Nomor 7/3/DPNP tentang Penilaian Kualitas Aktiva Bank Umum yang pada pokoknya mengatur ketentuan bank perlu memperhatikan upaya yang dilakukan debitur dalam rangka memelihara lingkungan hidup. 
Sehubungan dengan pengaturan pembiayaan kegiatan usaha tersebut, Deputi Gubernur Bank Indonesia Siti Ch Fadjrijah menyatakan bahwa Bank Indonesia akan memperbaiki peraturan bagi perbankan dalam pemberian pembiayaan kegiatan usaha yang berwawasan lingkungan dengan keharusan memberikan laporan audit lingkungan. Ketentuan Peraturan Bank Indonesia Nomor PBI 7/2/2005 sudah mengatur bahwa salah satu kriteria dalam menilai Kualitas Aktiva Produktif perbankan adalah adanya analisis lingkungan. Namun belum dimuat kriteria analisis lingkungan dalam aturan tersebut.

Kriteria penilaian dalam analisis lingkungan akan dimasukkan dalam Peraturan Bank Indonesia (PBI) yang baru atau memperbaiki PBI Nomor 7/2/2005 agar dalam pengajuan atau perpanjangan kredit besar harus ada laporan audit lingkungan yang dilakukan auditor independen yang diakui Kementerian Lingkungan Hidup. Aspek epistemologi dalam pengaturan hukum pembiayaan yang berprinsip lingkungan inheren kriteria penilaian dalam analisis lingkungan adalah mensistematisasi bahan-bahan hukum tersebut yang pada hakikat, tujuannya dan tuntutan penerapan pada kehidupan masyarakat secara nyata. Struktur logikal yang terbentuk dalam pengaturan hukum tersebut seyogyanya dapat menunjukkan kesatuan pemikiran dalam menjaga keberadaan kehidupan manusia.

\section{Aspek aksiologis}

Perubahan kondisi sumber daya alam dan lingkungan terjadi di berbagai wilayah di Indonesia. Kondisi lingkungan tersebut menunjukkan diantaranya penurunan kualitas dan ketersedian air karena adanya aliran sungai yang telah tercemar oleh limbah dari kalangan domestik maupun industri. Konsentrasi bahan kimia yang merupakan bahan pencemar telah diketemukan pada sungai yang mengalir di berbagai wilayah di Indonesia. Penurunan kualitas dan da- ya dukung lingkungan disebabkan ketidakmampuan kalangan industri mewujudkan pengelolaan kegiatan usahanya yang berwawasan lingkungan.

Perbankan sebagai penyedia dana bagi penelenggaraan kegiatan perekonomian sesungguhnya mempunyai peran yang sangat strategis dalam upayanya untuk mengendalikan pencemaran dan perusakkan lingkungan. Kebijakan bank dalam penyaluran dana adalah memberikan perlakuan khusus baik sebelum maupun dalam penyaluran dana bagi kegiatan usaha nasabah yang berpotensi menimbulkan pencemaran dan atau perusakkan lingkungan. Dengan perlakuan bank tersebut diharapkan nasabah bank yang menjalankan kegiatan usaha tetap dapat menjaga kualitas dan daya dukung lingkungan hidup. Dan aspek aksiologis dalam hukum pembiayaan kegiatan usaha adalah mengkaji penerapan hukum pembiayaan kegiatan usaha yang berprinsip lingkungan terhadap perjanjian pembiayaan kegiatan usaha yang dibakukan oleh Bank-Bank yang menjalankan kegiatan operasionalnya.

Kementerian Lingkungan Hidup dengan Bank Indonesia telah berkerjasama dalam penerapan hukum pembiayaan kegiatan usahayangberprinsiplingkungan.Penerapan hukum tersebut melalui pengelolaan Two Step Loan lingkungan JBIC-PAE yang dibiayai oleh JBIC Jepang dan IEPC-KfW yang dibiayai oleh KfW Jerman. Kerjasama tersebut telah berlangsung 10 tahun yang secara khusus Kementrian Lingkungan Hidup telah bekerjasama dengan kalangan perbankan, diantaranya dengan Bank BNI, BCA, BII, Bank Danamon, Bank Mandiri, Bank Lippo, BPD Jawa Barat, BPD Jawa Tengah, BPD Bali, dan BPD Sumatera Barat. ${ }^{18}$

\footnotetext{
${ }^{18}$ Siaran Pers Bersama Bank Indonesia dan Kementerian Negara Lingkungan Hidup No.6/105/B. Gub/Humas tentang Peran Serta Sektor Perbankan dalam Pengelolaan Lingkungan Hidup Meningkat, 8 September 2004
} 


\section{Aspek Ideologi}

Peristilahan UUD 1945 sebagai Green Constitution disampaikan oleh Jimmly Asshidiqie dengan berdasarkan pemahaman yang mendalam mengenai kerusakan lingkungan hidup sehingga perlu diletakkan suatu dasar-dasar konseptual mengenai persoalan lingkungan hidup dan pembangunan (sustainable development) dengan berwawasan lingkungan. Berikutnya, Undang-Undang Dasar 1945 sebagai the supreme law of the land pada dasarnya telah memuat gagasan dasar mengenai kedaulatan lingkungan yang dapat disetarakan dengan konsep demokrasi dan nomokrasi. ${ }^{19}$

Substansi green constitution itu telah dimuat dalam amandemen ke-empat UUD 1945 Pasal 33 ayat (4) yang mengatur Perekonomian nasional diselenggarakan berdasar atas demokrasi ekonomi dengan prinsip kebersamaan, efisiensi berkeadilan, berkelanjutan, berwawasan lingkungan, kemandirian serta dengan menjaga keseimbangan kemajuan dan kesatuan ekonomi nasional. Gagasan Green Constitution, kedaulatan lingkungan maupun konsepsi demokrasi model baru yang diistilahkan ekokrasi (ecocracy) merupakan pencerminan dari Pasal $28 \mathrm{H}$ ayat (1) dan Pasal 33 ayat (4) UUD 1945.20

Negara Republik Indonesia menganut tipe negara modern, welfare state type. Di dalam mewujudkan kesejahteraan kehidupan warganya, negara Republik Indonesia meletakkan konsep green constitution yaitu penyelenggaraan kehidupan bernegara dan berbangsa yang bersendikan pada upaya pelestarian fungsi lingkungan hidup sehingga dapat mewujudkan terciptanya masyarakat adil, makmur dan merata. Penggunaan konsepsi negara kesejahteraan bagi negara Republik Indonesia akan tampak dari dua fungsi yang dijalankan yakni fungsi regular (regularity function) dan fungsi pembangunan (developing function). Fungsi yang bersifat regular, sering disebut fungsi rutin,

${ }^{19}$ Jimmly asshiddiqie, $\mathrm{h} . \mathrm{X}$

${ }^{20}$ Jimmly Asshiddiqiqie,h. 5 yang harus dilaksanakan oleh negara demi kelangsungan kehidupan bernegara. Sedangkan fungsi pembangunan merupakan fungsi yang bertujuan untuk meningkatkan kesejahteraan masyarakat, seperti halnya pelestarian fungsi lingkungan hidup dalam kegiatan perekonomian yang berkembang di masyarakat.

\section{Implikasi Prinsip-Prinsip Penyelenggaraan Kegiatan Ekonomi menurut Pasal 33 UUD 1945 terhadap Pembentukan Hukum Ekonomi}

\section{Interelasi pembangunan nasional terhadap pembangunan ekonomi berkelanjutan}

Konsep yang termuat dalam UUD 1945 adalah pengaturan mengenai sustainable development (pembangunan berkelanjutan). Peristilahan pembangunan berkelanjutan (sustainable development) dalam United Nations Conference on Human Environment (UNCHE) diStockholm, Swedia pada tahun 1972 adalah prinsip pelestarian fungsi lingkungan hidup dalam pengelolaan sumber daya alam yang bertujuan untuk kepentingan generasi yang hidup masa kini maupun yang akan datang. Konsep pembangunan dilaksanakan secara berkelanjutan telah mengakomodasikan berbagai kepentingan diantaranya manusia dalam memenuhi kebutuhan hidupnya yang telah disediakan oleh alam disekitar kehidupannya. Pembangunan berkelanjutan yang menjadi karakter pembangunan nasional berpijak pada kepentingan manusia dengan alam yang meliputi enviromental sustainability, economy sustainability dan sociopolitical. Interelasi ketiganya dalam memformulasikan nilai, konsep dan penormaan pembangunan nasional untuk mecapai tujuan bernegara sebagaimana yang termuat dalam Pembukaan UUD 1945.

Tujuan bernegara akan dapat diwujudkan manakala masyarakat yang berkomitmen membangun bersinergi dengan kelembagaan pemerintah atau yang berkepentingan untuk menggerakkan segala potensi pembangunan dan meminimalkan berbagai kendala dan 
tantangan. Sumber daya alam dimanfaatkan untuk sebesar-besarnya kemakmuran rakyat dengan tetap memperhatikan kelestarian fungsi lingkungan hidupnya. Sumber daya alam memiliki peran ganda, yaitu sebagai modal pertumbuhan ekonomi (resource based economy) dan sekaligus sebagai penopang sistem kehidupan (life support system).

Pada saat ini, sumber daya alam sangat berperan sebagai tulang punggung perekonomian nasional, dan masih akan diandalkan dalam jangka menengah. Namun di lain pihak, kebijakan ekonomi yang lebih berpihak pada pertumbuhan jangka pendek telah memicu pola produksi dan konsumsi yang agresif, eksploitatif, dan ekspansif sehingga daya dukung dan fungsi lingkungan hidupnya semakin menurun, bahkan mengarah pada kondisi yang mengkhawatirkan. Atas dasar fungsi ganda tersebut, sumber daya alam senantiasa harus dikelola secara seimbang untuk menjamin keberlanjutan pembangunan. Penerapan prinsip-prinsip pembangunan yang berkelanjutan (sustainable development) di seluruh sector dan wilayah menjadi prasyarat utama untuk diinternalisasikan ke dalam kebijakan dan peraturan perundangan, terutama dalam mendorong investasi pembangunan jangka menengah (2004-2009). Prinsip-prinsip tersebut saling sinergis dan melengkapi dengan pengembangan tata pemerintahan yang baik (good governance) yang mendasarkan pada asas partisipasi, transparansi, dan akuntabilitas yang mendorong upaya perbaikan pengelolaan sumber daya alam dan pelestarian fungsi lingkungan hidup.

\section{Pembentukan hukum ekonomi pembangunan Indonesia berdasarkan prinsip pelestarian lingkungan hidup}

Penyelenggaraan pembangunan yang beraspek lingkungan hidup berlangsung selama Pemerintahan dibawah Presiden Soeharto dengan membentuk Kementerian Lingkungan Hidup. Dalam kurun waktu sepuluh tahun setelah Konferensi PBB di Swedia maka pada tahun 1982 telah di Undangkan Undang-Undang Nomor 4 Tahun 1982 (LN 1982 No. 12) tentang ketentuan-ketentuan pokok Pengelolaan Lingkungan hidup secara terpadu dengan mengamanatkan keharusan untuk mengkaitkan pelaksanaan pembangunan dengan pengelolaan lingkungan hidup melalui apa yang dinamakan "pembangunan berwawasan lingkungan"

Pengaturan konsepsi pembangunan berwawasan lingkungan dalam Undang-Undang Lingkungan Hidup ini memberikan pemahaman baru bagi penyelenggaraan penyenggaranpembangunannasinalyangsedang berlangsung sebagaimana diamanatkan dalam Pasal 4 huruf d Undang-Undang Lingkungan Hidup yang mengatur bahwa salah satu tujuan pengelolaan lingkungan hidup adalah pembangunan berwawasan lingkungan untuk kepentingan generasi sekarang dan mendatang. Berikutnya, di dalam Pasal 3 Undang-Undang Lingkungan Hidup yang memuat tentang asas pengelolaan lingkungan hidup mengatur pengelolaan Lingkungan Hidup Berazaskan Pelestarian Kemampuan Lingkungan yang serasi dan seimbang untuk menunjang pembangunan yang berkesinambungan bagi peningkatan kesejahteraan manusia.

Dalam perkembangan selanjutnya UU No. 4 Tahun 1982 dicabut dan digantikan dengan Undang-Undang Nomor 23 Tahun 1997 (LN 1997:68) tentang pengelolaan Lingkungan Hidup. Undang-Undang Nomor 23 Tahun 1997 menggunakan peristilahan Pembangunan Berkelanjutan Yang Berwawasan Lingkungan Hidup. Penyelenggaraan Pembangunan Berkelanjutan Yang Berwawasan Lingkungan Hidup menurut pertimbangan UU No. 23 Tahun 1997 antara lain dalam rangka mendayagunakan sumberdaya alam untuk memajukan kesejahteraan umum seperti diamanatkan dalam UUD 1945 dan untuk mencapai kebahagiaan hidup berdasarkan Pancasila, perlu dilaksanakan pembangunan berkelanjutan yang berwawasan lingkungan hidup berdasarkan kebijaksanaan nasional 
yang terpadu dan menyeluruh dengan memperhitungkan kebutuhan generasi masa kini dan generasi masa depan.

Undang Undang Nomor 32 Tahun 1997 mengatur suatu rumusan tentang pembangunan berkelanjutan yang berwawasan lingkungan hidup (pasal 1 butir 3). Disebutkan dalam ketentuan tersebutbahwa pembangunan berkelanjutan yang berwawasan lingkungan hidup adalah upaya sadar dan terencana, yang memadukan lingkungan hidup, termasuk sumber daya ke dalam proses pembangunan untuk menjamin kemampuan, kesejahteraan dan mutu hidup generasi masa kini dan masa depan. Berikutnya dalam Undang-Undang tersebut menjelaskan "asas keberlanjutan" sebagai asas pengelolaan lingkungan hidup dan "pembangunan berwawasan lingkungan hidup" sebagai suatu sistem pembangunan. Hal ini dapat dilihat dalam pasal 3 yang menyatakan:"pengelolaan lingkungan hidup diselenggarakan dengan asas tanggung jawab negara, asas keberlanjutan, dan asas manfaat bertujuan untuk mewujudkan pembangunan berkelanjutan yang berwawasan lingkungan hidup dalam rangka pembangunan manusia Indonesia seluruhnya yang beriman dan bertaqwa kepada Tuhan Yang Maha Esa.

Dan implikasi prinsip-prinsip penyelenggaraan kegiatan ekonomi menurut Pasal 33 UUD 1945 terhadap pembentukan hukum ekonomi pembangunan Indonesia yaitu telah dilakukan perubahan yang mendasar pada cara pandang, konsep pembangunannasional yang terintegrasi dengan pembangunan berkelanjutan sehingga dibutuhkan pola baru menuju penormaan hukum ekonomi pembangunan berkelanjutan. Pemahaman langkah perubahan yang mendasar dalam carapandang, konsep pembangunannasional yang terintegrasi dengan pembangunan berkelanjutan ini merujuk pada teori Hukum Pembangunan yang memfungsikan peran hukum dalam aktivitas penyelenggaraan pembangunan nasional.

\section{Kesimpulan}

Karakteristik pengaturan konsep green constitution dalam penyelenggaraan kegiatan ekonomi merujuk pada hakikat kehidupan manusia dalam kehidupan berbangsa dan bernegara Pancasila yang senantiasa menjaga hubungan yang serasi selaras dan seimbang dengan alam sebagai tempat kehidupannnya. Mekanisme hukum penyelenggaraan kegiatan ekonomi yang berkelanjutan berlandasakan pada prinsipprinsip perekonomian nasional sebagaimana diamanatkan oleh Pasal 33 UUD 1945. Tujuan bernegara Indonesia telah dicantumkan dalam Pembukaan yang memberi arah dan nilai perjuangan dalam menyelenggarakan kegiatan ekonomi. Dan implikasi prinsipprinsip penyelenggaraan kegiatan ekonomi menurut Pasal 33 UUD 1945 terhadap pembentukan hukum ekonomi pembangunan Indonesia yaitu telah dilakukan perubahan yang mendasar pada cara pandang, konsep pembangunan nasional yang terintegrasi dengan pembangunan berkelanjutan sehingga dibutuhkan pola baru menuju penormaan hukum ekonomi pembangunan berkelanjutan.

\section{Saran}

Karakteristik hukum kegiatan ekonomi berkelanjutan yang telah dipahami baik dari sisi hakikat, mekanisme, tujuan den ideologinya sejogyanya secara konsisten dapat diterapkan dalam penyelenggaraan pembangunan nasional yang berorientasi pada pembangunan berkelanjutan. Cara pandang, nilai-nilai dan konsep pembangunan nasional yang telah berintegrasi dengan pembangunan berkelanjutan bukan hanya untuk memenuhi tuntutan formalitas belaka dalam tujuan bernegara akan tetapi sejogyanya dapat menemukan tujuan bernegara yang secara substansial menjadi agenda pokok tujuan bernegara sampai akhir zaman. 


\section{DAFTAR PUSTAKA}

Sinaga, Budiman. 2005. Hukum Konstitusi. Yogyakarta: Kurnia Kalam Semesta.

Thaib, Dahlan. et.al., 1999. Teori dan Hukum Konstitusi (Edisi Revisi). Jakarta: Rajawali Pers.

Thaib, Dahlan. (Editor), 1998. Hukum dan Kekuasaan. Yogyakarta: FH UII Pers.

Abdillah, Mujiyono. 2001. Agama Ramah Lingkungan Perspektif Al-Qur'an. Jakarta: Paramadina.

Abdillah, Mujiyono. 2005. Fikih Lingkungan (panduan Spritual Berwawasan Lingkungan). Yogyakarta: UPP AMP YKPN.

Fadjar, Mukhtie. Reformasi Konstitusi dalam Masa Transisi Paradigmatik, Pidato Pengukuhan Guru Besar dalam Ilmu Hukum Pada Fakultas Hukum Universitas Brawijaya Malang, 13 Juli 2002.

Fadjar, Mukhtie. 2004. Negara Hukum,
Bayumedia, Malang.

R.M. A.B. Kusuma, 2009, Lahirnya UndangUndang Dasar 1945 (Memuat Salinan Dokumen Otentik Badan Oentoek Menyelidiki Oesaha-Oesaha Persiapan Kemerdekaan),BadanPenerbitFakultas Hukum Universitas Indonesia.

Undang-Undang Dasar Republik Indonesia Tahun 1945

Undang-Undang Nomor 22 Tahun 2001 tentang Minyak Bumi dan Gas Alam

Undang-Undang Nomor 20 Tahun 2003 tentang Ketenagalistrikan.

Undang-Undang Nomor 7 Tahun 2004 Pengelolaan Sumber Daya Air

Undang-Undang Nomor 10 Tahun 2004 Pembentukan Peraturan Perundangundangan.

Undang-Undang Nomor 32 Tahun 2009 tentang Pengelolaan Lingkungan Hidup 